\title{
NILAI ESTETIS MUSIK DALAM RENTANG SEJARAH MUSIK BARAT
}

\author{
Supriyadi \\ Institut Seni Indonesia Yogyakarta
}

\begin{abstract}
Abstrak
Sejarah musik Barat, secara historis, telah berubah sejak lama; dari satu periode ke periode lain sampai hari ini. Dalam musik, chaging secara otomatis mengubah bentuk, gaya, karakteristik, harmoni, dan terutama nilai-nilai estetika. Kemudian, perubahan memicu perkembangan. Secara dominan pembangunan dipengaruhi oleh dua aspek dominan, yaitu aspek internal dan aspek eksternal. Sejarah musik mengatakan bahwa periode Abad Pertengahan dipengaruhi oleh agama politik yang ditempatkan di bawah otorisasi gereja Katolik. Masa Renaisance dipengaruhi oleh semangat individualisme dan humanisme, dan juga antusiasme antroposentrisme. Era Barok dibayangi oleh perubahan politik di Eropa Barat. Periode Klasik dan Romantis diarsir oleh semangat ekspansi teritorial dan nasionalisme yang ditandai oleh Revolusi Franch. Setelah Perang Dunia I dan II perubahan sosial ditentukan oleh perkembangan teknologi. Itu menjadi faktor penting. Dalam konteks musikologi, perkembangan teknologi telah menciptakan beberapa instrumen musik baru. Hubungan antara aspek internal dan eksternal terjadi korelatif dan nilai-nilai estetika dalam musik telah dipengaruhi oleh beberapa aspek di atas. Keberadaan musik tidak disebabkan oleh dirinya sendiri, tetapi dipengaruhi oleh aspek lain.
\end{abstract}

Kata kunci: aspek eksternal; aspek internal; estetika; pengaruh; perubahan

\begin{abstract}
The history of Western music, historically, has been changing for a long time; from one period to other period until the present day. In music, the chaging automatically changes its forms, styles, characteristics, harmony, and particularly its aesthetics values. Then, the changing triggers development. Dominantly the development is inluenced by two dominant aspects, i.e. internal aspect and external aspect. The music history said that the period of Middle Ages was influenced by political religion which was placed under Chatolic church authorization. Renaisance period was influenced by spirit of individualism and humanism, and also enthusiasm of anthropocentrism. The Barock era was shadowed by the political changing in Western Europe. The Classic dan Romantic period was shaded by the passion of territorial expansion and nationalism that was marked by Franch Revolution. After World War I and II the social changes were determined by the development of technology. It becomes significant factor. In musicology context, the development of technology has created several new music instruments. The relationship between internal and external aspect occurs correlative and the aesthetics values in music has been influenced by several aspects above. The existence of music is not caused by itself, but it influenced by another aspects.
\end{abstract}

Keywords: internal aspect; external aspect; aesthetics; influence; change

\section{Pendahuluan}

Musik Barat dalam sejarahnya memiliki sistem tersendiri. Istilah 'Barat' spesifik mengacu pada suatu wilayah di benua Eropa dan Amerika. Akan tetapi oleh karena perkembangan musik di Eropa telah berkembang jauh sebelum ditemukannya benua Amerika oleh Christopher Colombus pada tahun 1492, maka sekurang-kurangnya sampai kurun waktu abad 19, istilah Barat di sini lebih mengacu pada benua Eropa, terutama yang terkait di beberapa wilayah yakni Italia, Jerman, Perancis, Austria, dan juga Inggris. Italia, 
mungkin tidak terlalu berlebihan jika disebutkan terlebih dahulu mengingat tradisi musik Gregorian (plainsong/ plainchant), yang menjadi cikal-bakal musik Barat, berada dari tradisi Gereja Katolik Roma di Italia sebagai pusatnya. Dari Italia inilah tradisi musik Barat akhirnya berkembang ke negara-negara yang telah disebutkan tadi, bahkan ke negara-negara lain seperti Rusia, Polandia, Belanda, dan Swedia.

Secara musikologis, istilah 'musik Barat' (lihat Kupferberg, 1985, p. 10-15) secara spesifik pula ditekankan untuk membedakan dengan yang disebut 'musik Timur'2 (Fernandez, 1990, p. 29-30; Nakagawa, 2000, p. 8-27) yakni, musik-musik yang secara umum berkembang di kawasan Asia seperti Cina, Jepang, India, Jawa, dan musik-musik oriental sebagainya. Dalam pembedaan itu, musik Barat ditandai dengan adanya tangga nada diatonis (baik Mayor maupun Minor), sedangkan musik Timur lebih banyak menggunakan tangga nada pentatonis, yakni sistem lima nada, walaupun di setiap wilayah memiliki model modus yang berbeda serta dibedakan pula dari jenis-jenis alat musiknya. Perkembangan alat musik Barat sangat berkaitan erat dengan perkembangan estetika di dalam tradisi musik Barat. Dengan kata lain, di dalam tradisi musik Barat, nilai estetis musik sangat berekaitan erat dengan perkembangan instrumen secara organologis.

Pembedaan ini sekurang-kurangnya menimbulkan konsekuensi logis. Sebagai misal istilah 'klasik' memiliki makna yang berbeda di musik Barat dan di musik Timur. Jika di Timur istilah ini relatif hanya mengacu pada satu makna dasar, yakni 'kuno', 'eksotis', 'primitif', 'stagnan', atau berkaitan dengan masa lalu (Merriam, 1995, p. 2-5), di Barat istilah 'klasik' memiliki makna yang beragam. Dalam perspektif Renaisans, era Yunani kuno (dengan tokoh seperti Socrates, Plato, Aristoteles, Pericles, Anaximandros dan sebagainya) termasuk zaman klasik; musik-musik yang terdapat di dalam rentang sejarah musik Barat (Abad Pertengahan, Renaisans, Barok, Klasik, Romantik, Post-Romantik, Neo-Klasik, dan Modern) disebut "musik klasik". Periode Klasik dalam rentang sejarah musik Barat boleh dikatakan 'musik klasik' dalam arti genre. Suatu metode dengan membagi durasi-durasi waktu ke dalam periode-periode merupakan cara pandang historis yang umum.

Analisis perubahan didasarkan pada teori perubahan Alvin Boskoff (1964) yang mendasarkan diri pada analisis penyebab eksternal dan internal. Tulisan ini tentu saja tidak

\footnotetext{
${ }^{1}$ Para musikolog membagi periode musikal ini secara berbeda-beda. Herbert Kupferberg membagi menjadi beberapa periode, yakni Middle Ages, Renaisance, Baroque, Classial, Romantic, Nationalist, PostRomantic, Impresionist, dan Modern.

${ }^{2}$ Pembedaan ini lebih spesifik terletak pada karakteristik 'dunia batin' bersifat 'ke dalam', 'kontemplatif'. Dan manusia adalah mikrokosmos.
} 
dimaksudkan untuk memaparkan fakta-fakta musikal secara detail dalam rentang sejarah musik Barat, akan tetapi lebih melihat fenomena sosial di setiap periode yang menyebabkan berubah dan berkembangnya nilai-nilai estetis musik. Oleh karena itu periode sejarah musik yang menjadi pokok bahasan agak berbeda dengan dimunculkan oleh sejarawan/ musikolog. Periode-periode tersebut adalah periode Abad Pertengahan, Renaisans, Barok dan Klasik, Romantik, serta Modern.

\section{Periode Abad Pertengahan}

Awal dan akhir Abad Pertegahan terus menjadi bahan perdebatan para musikolog dan sejarawan. Tapi secara umum dapat dikatakan, Abad Pertengahan dimulai bersamaan dengan runtuhya kekaisaran Romawi bagian barat tahun 476 CE sampai masa Renaisans di Abad ke-15. Istilah ini untuk pertama kali disebut oleh Flavio Bionco dalam Historiarum ab Inclinatione Romanorum Imperii Decades (Decades of History from the Deterioration of the Roman Empire) tahun 1483, untuk menunjukkan 'ketertundaan waktu', yakni suatu periode stagnasi kultural. Ada dua pandangan besar mengenai pembagian periode ini. Pertama, Abad Pertengahan dibagi dua situasi Dark Ages yaitu 476 CE-1000 CE (Kamien, 1994, p. 57-64). Inilah masa stagnasi ilmu pengetahuan. Kedua, Middle Ages (1000 CE$1500 \mathrm{CE}$ ) dengan munculnya ilmu pengetahuan, walaupun dalam kuantitas dan kualitas yang belum besar.

Sejarawan lain membagi periode ini menjadi tiga situasi. Pertama, Early Middle Ages, biasa disebut Late Antiquity: awal abad ke-5-abad ke-10 Masehi. Dengan runtuhnya Romawi, maka tidak ada kerajaan yang dominan, namun Gereja Katolik justru berkembang dan mempengaruhi dunia politik. Kedua, High Middle Ages: abad ke-10 sampai abad ke-13 Masehi. Gereja Katolik bukan hanya berpengaruh di Italia tetapi juga di seluruh Eropa dan menjadi faktor pemicu Perang Salib. Bidang teologi dan filsafat bergaya skolastikisme berkembang. Ketiga, Late Middle Ages yaitu abad 3-5 M. Sekularisme mulai berkembang dan menciptakan persaingan antara negara dan Gereja. Hal ini menjadi pemicu munculnya peradaban Renaisans dan Reformasi Protestan di abad ke-16.

Kekuasaan Gereja Katolik berpengaruh ke segala bidang, termasuk dunia musik karena Gereja menjadi pusat dari segala bentuk pengajaran. Oleh karena itu bentuk musik pada saat itu bersifat religius. Bentuk musik vokal sangat berkembang di dalam biara dengan gaya monofoni, sementara musik di luar gereja hanya sedikit. Istilah 'sedikit' di sini harus dimaklumi sebab sebagian besar manuskrip berasal dari dalam biara yang 
disebabkan pula oleh sangat minimnya masyarakat di luar gereja (awam) yang memiliki kemampuan keberaksaraan. Itu pula yang menjadi sebab penafsiran terhadap Alkitab menjadi monopoli para clerus (kaum padri katolik) karena Alkitab sangat sulit didapatkan di luar biara.

Semua musik harus dikaitkan dengan kehidupan liturgis: mengiringi Mazmur (book of Psalms) atau aspek-aspek yang berkaitan dengan ibadah Katolik, di antaranya yang berkaitan dengan ordinarium atau propium. Namun muncul sisi positif yang menjadi tonggak dalam perkembangan musikologi dunia yakni disusunnya musik Gregorian oleh Paus Gregorius Agung (590-604 CE). Bahasa yang digunakan untuk kepentingan liturgis adalah Bahasa Latin, setidaknya sampai Konsili Vatikan II (1962-1965). Musik Gregorian dianggap sangat berpengaruh bagi ibadah katolik sangat terlihat pada surat yang ditulis Paus Leo IV (847-855) kepada salah seorang pemimpin biara, yang di dalamnya terdapat istilah Carmen Gregorianum (nyanyian Gregorian). Ada tiga gaya dalam musik jenis ini, yakni syllabic style, neumatic style, dan melismatic style atau biasa juga disebut florid style. Simbol yang digunakan disebut neumes. Modus-modus otentiknya meliputi: dorian, phrygian, dan lydian, dengan bentukan plagalnya: hypodorian, hipophrygian, hypolydian, dan hypomixolydian. Umumnya musik ini memiliki beberapa bentuk, yakni accentus atau psalmodi, concentus, tropus, sekuensi, dan mysterienspiel (Kamien, 1994, p. 30-47; Apel, 1972, p. 326-337; Noth, 1990) $)^{3}$.

Pada tahun 1050 Guido d'Arezzo merupakan seorang musikolog Italia menciptakan suatu metode menghafal nada yang didasarkan pada hexachord, suatu deretan enam nada. Keenam nada tersebut diambil dari John's Hymn-Kidung Yohanes-(Martopo, 2015, p. 84-85). Keenam suku kata tersebut adalah $u t$, re, mi, fa, sol, la. Jarak setengah nada di antara nada $m i$ dan $f a$ bersifat permanen. Artinya, keenam suku kata tersebut menunjukkan posisi-posisi nada yang relatif sehingga membentuk tiga jenis hexachord standar, yaitu hexachord natural (naturalis) $=$ C D E F G A; soft (molle) $=$ F G A B ${ }^{\mathrm{b}} \mathrm{C} \mathrm{D}$; hard (durum) $=\mathrm{G}$ A B C D E. Bentuk solmisasi semacam ini memungkinkan penyanyi untuk menghafal urutan nada dengan mudah meski tinggi nadanya berubah-ubah dalam paranada (Kupferberg, 1985, p. 42). Sistem yang diciptakan Guido ini terbukti sangat bermanfaat dalam perkembangan musik di masa itu. Pengaruh-pengaruh semacam ini juga dapat dilihat dari karya-karya Giovanni Pierluigi Palestrina.

\footnotetext{
${ }^{3}$ Bahwa simbol-simbol tersebut pada akhirnya menyiratkan reference tertentu.
} 
Musik sebagian besar didominasi oleh Gereja. Maka ada pula musik di luar gereja, yakni troubadour dan travere. Yang pertama berkembang di Perancis Selatan, sedangkan yang kedua berkembang di Perancis Utara. Tema-tema musik ini tidak religius atau berkaitan dengan ibadah, tetapi bersifat sekular. Temanya berkisar percintaan, politik, ksatria, perang, alam, dan sebagainya. Walaupun demikian, manuskrip dari bentuk-bentuk musik ini tetap saja sangat terbatas; jauh lebih sedikit dibandingkan musik-musik di dalam biara sehingga agak sulit membuat abstraksi musikal dari musik ini. Kemunculan jenis musik ini terjadi di fase ketiga Abad Pertengahan, seperti dikatakan Hamilton, "There emerged a dichotomy between a low, sensual, instrumental, secular music, and an exalted, intellectual, vocal, sacred music" (Hamilton, 2007, p. 32).

Dari perkembangan Gereja Katolik dan bentuk-bentuk musik di atas menjadi jelas bahwa perkembangan musik sangat dipengaruhi faktor eksternal dan internal. Faktor eksternal, yakni politik Gereja Katolik sangat mempengaruhi perkembangan musik. Musik harus 'menghamba' pada kepentingan Gereja sebab semua bidang harus bersumber pada pemahaman wahyu di dalam Alkitab, tradisi dan magisterium. Dengan kata lain, perubahan atau perkembangan musik sangat tergantung pada kepentingan Gereja Katolik. Di sisi lain, munculnya musik Gregorian merupakan indikator penting adanya perubahan yang bersifat internal. Perubahan musik ini diinginkan oleh komunitas tertentu, yang dalam hal ini adalah Gereja Katolik sebagai hierarki. Pendeknya, di masa Abad Pertengahan nilai-nilai estetis musik dibangun di bawah otoriterisasi lembaga keagamaan (religius), yang seperti halnya bidang-bidang lain, mengalami stagnasi yang luar biasa, namun di sisi lain cakrawala simbolisasi musik mendapatkan tempatnya yang paling cermerlang demi perubahan nilai-nilai di masa-masa berikutnya.

\section{Periode Renaisans}

Secara literal 'renaisans' (renaissance) berarti 'kelahiran kembali' (rebirth). Nama lain dari istilah ini adalah 'fajar budi', 'aufklarung', 'pencerahan' (enlightment), atau 'kebangkitan kembali'. Renaisans mungkin lebih tepat disebut 'peradaban' ketimbang 'periode', sebab masa pencerahan ini memiliki rentang yang sangat panjang. Periode Barok dan Klasik pada dasarnya juga masih berada di dalam semangat renaisans. Istilah 'renaisans' pertama kali dipergunakan oleh sejarawan Perancis bernama Jules Michelet pada tahun 1855 untuk menunjuk pada 'penemuan dunia dan manusia'; sebuah pandangan yang berkembang di abad ke-16. Kemudian sejarawan besar Swiss, Jacob Burkhardt, 
dalam karyanya The Civilization of the Renaissance in Italy (1860) memperluas pandangan Michelet sebagai masa hidup dua seniman besar: Giotta dan Michelangelo (Kamien, 1994, p. 67-70). Dalam buku itu, ia menunjuk karakteristik masa ini sebagai kelahiran manusia modern dan kesadaran setelah mengalami kemerosotan, terutama dalam hal rasionalitas. Renaisans adalah sebuah semangat besar dalam rangka kembali kepada pemikiranpemikiran Yunani yang rasional, sejak Socrates mendekonstruksi pandangan mitologis Yunani Kuno.

Pada masa ini banyak peristiwa penting yang tercatat sebagai sejarah dunia, yakni: (1) Kejatuhan kota Konstantinopel atau Bizantium ke tangan Turki tahun 1453, (2) Eksplorasi samudera oleh penjelajah, sekaligus penemuan dunia baru oleh Christopher Columbus pada tahun 1492 setelah ditemukannya alat penunjuk arah atau kompas, (3) Hal itu juga disebabkan oleh adanya pembaruan astronomi yang semula memakai sistem Ptolomeus dengan geocentrisnya menjadi heliocentris oleh tokoh-tokoh seperti Nicolaus Copernicus, Galileo Galilei, dan Johannes Kepler, (4) Penolakan sistem feodal seiring bertumbuhnya perdagangan, (5) Penemuan benda-benda dengan inovasi luar biasa seperti kertas, bubuk mesiu, dan mesin cetak oleh Johann Gutenberg di tahun 1450, dan (6) Reformasi Protestanisme yang dipelopori oleh Martin Luther tahun 1517 di Jerman (Kamien, 1994, p. 64-67).

Peristiwa-peristiwa tersebut selanjutnya memunculkan kerakteristik-karateristik baru yakni:

1. Kebangkitan humanisme

Gerakan yang bermula dari Italia ini menyebar ke seluruh penjuru Eropa. Menjadikan manusia sebagai subjek, menekankan pentingnya martabat manusia, dan mengupayakan pencarian akan hikmat dan jati diri manusia melalui pengkonsolidasian spiritualitas baru dan pemujaan akan ilmu pengetahuan. Pandangan ini dipelopori oleh penyair Italia Dante Alighieri (1265-1321). Di luar Italia terdapat sastrawan Desiderius Erasmus (c.1466-1536). Negara Perancis merupakan pusat dari pemikiran-pemikiran peradaban Renaisans. Dari sanalah muncul pemikir-pemikir yang punya pengaruh besar seperti Francois Marie Arouet, Voltaire, Montesquieu yang menulis The Spirit of Law yang membagi pemerintahan menjadi tiga kekuasaan, yakni legislatif, eksekutif, dan legislative (Daniels, Patricia S dan Stephen G, 2003, p. 210-211). 


\section{Kebangkitan Seni}

Di bidang seni rupa, perubahan besar terjadi di kota Florence, Italia, tahun 1420, dengan ditemukannya ilmu perspektif lewat metode tiga dimensi sehingga mengesampingkan metode bidang datar. Berkembangnya teknik melukis anatomi tubuh manusia sebagai objek lukisan. Seni patung mulai mendominasi dengan munculnya subjek-subjek klasik. Dalam bidang arsitektur gaya-gaya Romawi-Yunani mulai mendominasi. Tokoh-tokohnya adalah Raphael, Donatello, Botticelli, Leonardo da Vinci, dan Michelangelo.

\section{Berkembangnya ilmu pengetahuan dan teknologi}

Bidang astronomi mengalami perkembangan yang sangat signifikan atas upaya Copernicus, Galileo, dan Kepler. Bidang kedokteran pun berkembang dengan pesat, terutama setelah diterjemahkannya karya-karya Hippokrates dan Galen pada abad ke-15 dan 16. Berkembangnya mesin cetak juga tak kalah penting pengaruhnya secara sosial sebab Alkitab yang sebelumnya dimonopoli oleh para klerus di biara-biara menjadi tersebar luas di masyarakat sehingga siapa pun boleh dan bisa menafsirakan Kitab Suci itu.

Secara umum dapat disimpulkan bahwa terdapat tiga komponen utama yang membentuk gaya renaisans, yakni (1) kebangkitan bentuk-bentuk klasik yang aslinya dikembangkan oleh kebudayaan Yunani Kuno dan Romawi, (2) penitikberatan pada kehidupan sekular, terutama minat yang kuat pada humanisme dan penekanan akan pentingnya peran dan eksistensi individu, dan (3) penitikberatan perkembangan hanya pada empat bidang, yakni filsafat, arsitektur, ilmu pengetahuan, dan sastra.

Secara umum musik tidak banyak mendapat pengaruh dari perubahan peradaban besar ini sebab eksistensi musik masih berada dalam konteks gereja, yakni sebagai fungsi ibadah. Kendati renaisans menitikberatkan pada kehidupan sekular, perkembangan musik tidak sedahsyat di seni seni rupa; musik-musik sekular belum berkembang karena 'dijaga ketat' oleh gereja. Akan tetapi, bukan sama sekali tidak ada perubahan di dalam seni musik. Perubahan yang paling kentara adalah munculnya teknik polifoni, terutama untuk lagu vokal. Suara yang satu disesuaikan dengan suara lain dengan memakai melodi yang lebih mengalir dan menggunakan teknik imitasi; satu melodi tema awalnya dinyanyikan oleh satu suara, kemudian mengalami repetisi secara persis atau dengan modifikasi oleh suara yang lain. Dalam hal ini melodi tema berfungsi menyatukan karya musik yang bersangkutan. 
Pada masa ini pula susunan empat suara menjadi standar dan kian menentukan perkembangan bentuk paduan suara di zaman berikutnya. Suara contra tenor yang pada Abad Pertengahan merupakan penambahan terhadap tenor, kini dibagi dua menjadi suara tinggi (altus), dan suara rendah (bassus). Keduanya ditempatkan di bawah suara tenor. Sementara suara pokok (cantus firmus) kini mendapat nama superius (Latin=lebih tinggi) atau sopra (Italia=di atas). Maka mulailah diperkenalkan susunan SATB (sopran, alto, tenor, bass) dalam bentuk choral yang biasa dipakai di dalam ordinarium ${ }^{4}$ di dalam misa kudus di alam tradisi ibadah gereja Katolik. Tokoh yang paling terkenal di masa ini adalah Giovanni Pierluigi da Palestrina (c.1525-1594), seorang pemimpin musik di seminari Jesuit.

Secara filosofis pemaknaan syair di dalam musik di zaman ini juga masih berorientasi pada filosofi kristiani dan berpengaruh pada kaitan antara teks dan lagu. Para komponis pada zaman ini masih sangat memperhatikan spirit dan mood dari sebuah teks tetap dalam kerangka spiritualitas kristiani. Mereka memilih modus, melodi, dan ritme yang secocok (match) mungkin dengan teksnya. Kata-kata atau syair atau teks, acapkali dikembangkan dengan teknik text painting (word painting), yakni representasi musikal terhadap imaji kata atau kalimat tertentu. Sebagai misal, kalimat "turun dari surga" atau "Tuhan datang ke dunia" dipasangkan dengan sebuah alur melodi yang bergerak turun. Begitu pula dengan kata-kata "Allah", "tahta Allah", "rahmat", "surga”, "malaikat", "firdaus", "kemuliaan" dipasangkan dengan melodi yang cenderung bergerak naik. Sebaliknya kata-kata seperti "bumi”, “dosa”, “iblis", "turun”, "manusia", "kejahatan", "hukum", "kegelapan", dan "dunia" cenderung dipasangkan dengan melodi yang bergerak turun.

Hal lain yang tidak kalah penting untuk dicatat adalah pengaruh reformasi protestan yang berawal 31 Oktober 1517 oleh Martin Luther (1483-1546), seorang biarawan dari ordo Agustinus, yang mencantumkan 95 dalil di pintu gerbang Gereja Wittenburg. Upayanya dikutuk oleh Paus dan diasingkan oleh gereja Katolik Roma tahun 1521. Pada dasarnya Luther ingin mengakhiri penyimpangan yang dilakukan gereja Katolik Roma pada saat itu. Dalam konteks musik, Luther menegaskan, bahasa Latin bukan satu-satunya bahasa yang dipakai di dalam ibadah. Maka ia menggunakan bahasa dan idiom-idiom musik lokal untuk sarana ibadah. Pada gilirannya kaum protestan di tiap negara

\footnotetext{
${ }^{4}$ Ordinarium di dalam misa di dalam tradisi ibadah katolik meliputi Kyrie (Tuhan kasihanilah kami), Gloria in excelsis Deo (kemuliaan bagi Allah di tempat yang mahatinggi), Credo (pernyataan iman), Sanctus (kudus), dan Agnus Dei (Anak Domba Allah).
} 
mengembangkan bentuk-bentuk ibadah mereka sendiri dengan menggunakan bahasa lokal di negaranya. Inilah awal dari inkulturasi musik di gereja. Sebuah upaya yang pada akhirnya dipergunakan juga oleh gereja Katolik Roma melalui Konsili Vatikan II (19621965) namun justru cenderung ditinggalkan oleh gereja Protestan sendiri.

Dari pemaparan fakta-fakta di atas, terdapat dua pengaruh yang menyebabkan terjadinya perubahan estetika musik, yakni faktor internal dan eksternal. Faktor yang pertama merupakan faktor yang dominan dan signifikan, yakni perubahan yang berkaitan dengan fungsi ibadah dan bukan pengaruh dari hingar-bingar dari luar. Perubahan di bidang musik hanya terjadi pada teknik yang semata-mata dikaitkan dengan fungsi ibadah dan bukan karena pengaruh dari luar; pengaruh pandangan filsafat renaisans. Faktor yang kedua, walau bersifat eksternal, pada dasarnya tidak terkait dengan gerakan renaisans. Mungkin lebih tepat disebut faktor 'politik internal' gereja karena Martin Luther, sang pelopor itu sendiri, awalnya juga seorang biarawan Agustinus dalam naungan gereja Katolik Roma. Namun demikian, upaya inkulturasinya itu sekurang-kurangnya telah membawa perubahan besar, yakni inkulturasi yang tetap bergema hingga detik ini.

\section{Periode Barok dan Klasik}

Periode Barok dan Klasik dalam tulisan ini sengaja tidak dipisahkan sebab secara sosial periode ini tidak memiliki batas yang jelas. Artinya, fenomena sosial yang berlangsung di masa Barok masih berlangsung di masa Klasik. Hal ini sangat berbeda dengan pemilahan periode musik: Periode Barok berakhir di tahun 1750 bersamaan dengan kematian Johann Sebastian Bach, tokoh sentral Barok, dan sesudahnya mulai periode yang sungguh-sungguh baru dengan munculnya komponis W.A. Mozart dan F. Handel. Dalam konteks musikal, nilai estetis di kedua zaman ini memang sungguh-sungguh berbeda.

\section{Periode Barok}

Istilah 'Barok' diambil dari bahasa Portugis 'Barocco' yang berarti 'mutiara dalam bentuk yang tidak beraturan'. Para ahli berpendapat, istilah ini juga punya kemungkinan berasal dari bahasa Itali 'Baroco' dan biasa dipakai para filsuf Abad Pertengahan yang menunjuk pada argumen silogisme. Selain itu, istilah 'Barok' berasal dari seorang pelukis di abad ke-16, Frederigo Barroci. Namun demikian, dari ketiganya, para ahli sepakat dugaan yang pertamalah yang paling tepat. Sebagai gaya seni, istilah 'Barok' baru dipakai dalam buku Encyclopedie (1750) karya Denis Diderot (1713-1784). Awalnya, di abad ke- 
18, istilah 'Barok' tidak bermakna positif, melainkan negatif. Jadi awalnya istilah ini bukan pujian, tetapi cemoohan. Barok merupakan musik rendahan, kurang bermutu, berlebihan, bahkan merupakan musik yang mengalami dekadensi pasca-Renaisans yang gemilang. Musik Barok yang berada dalam periode 1600-1750 dianggap musik yang bernilai tinggi, bermutu oleh para komponis di abad ke-19, bahkan dianggap musik terbaik dalam sejarah musik Barat, terutama penitikberatan pada figur bas (bass continuo atau thorougbass), nada-nada disonan, dan kromatis yang banyak digunakan sebagai gaya dalam musik jazz sampai detik ini (Burkholder, et.al, 2005, p. 300-303).

Situasi sosial periode Barok diwarnai oleh pertentangan antara gereja Protestan dengan reformasinya melawan gereja Katolik Roma dengan kontra-reformasinya. Beberapa pertempuran terjadi akibat pertentangan itu dan kian menyebar hampir di seluruh Eropa. Selain itu, terjadi peningkatan aktivitas perdagangan dan meningkatnya posisi masyarakat kelas menengah. Eksploitasi terhadap 'dunia baru' Amerika juga mulai dilakukan Spanyol dan Portugis (di wilayah tengah dan selatan), serta Inggris dan Perancis (di wilayah utara) dan bahasa Perancis. Dimulailah kolonialisasi dengan gaya imperialis, termasuk oleh Belanda.

Beberapa bentuk, teknik, jenis, dan gaya musik justru berkembang di periode ini. Opera adalah bentuk musik yang berkembang di masa ini bersanding dengan gaya resitatif dan aria. Musik tak lagi berdiri sendiri. Ia mulai mendapatkan tempatnya sebagai kanalisasi ide dan emosi yang tertuang dalam cerita drama. Dalam konteks teknik musik, jelas sangat dipengaruhi oleh bidang arsitektur. Penggunaan teknik trill, turn, dan arpeggio sangat ramai di dalam karya-karya Barok. Akibatnya muncul kesan fleksibilitas dari segi ritmis yang berda dengan karya renaisans yang terkesan datar.

Dari segi harmoni, karya-karya Barok mengkodifikasikan prinsip progresi harmoni pada tangga nada mayor dan minor. Pemanfaatan bunyi disonan oleh para komponis Barok pun menjadi lebih leluasa dengan adanya nada pusat (tonal center), yang pada gilirannya menghasilkan chord progression. Di masa ini pula ditemukan sistem penalaan nada yang disebut equal temperament. Sistem ini dianggap sebagai penyempurnaan sistem penalaan Pythagoras. Bach menggunakan sistem tersebut lewat karyanya Well-tempered Clavier. Dengan berkembangnya polifoni, maka muncullah teknik kontrapung yang banyak terlihat dalam karya-karya madrigal. Selain madrigal bentuk-bentuk yang berkembang di masa itu adalah cantata, oratorio, suita, sonata, dan orkestra, serta konserto, selain juga bentuk fuga, dan overture. 


\section{Periode Klasik}

'Klasik' adalah istilah yang sangat umum sehingga memiliki pengertian yang sangat beragam, bahkan istilah ini memiliki pengertian yang berbeda di berbagai bidang, bahkan di bidang yang paling dekat. Sering juga istilah ini dirujuk dari akar kata 'class' yang berarti seni untuk golongan bangsawan (musik bermutu tinggi). Patricia menulis menulis sebagai berikut.

\footnotetext{
The very words 'classic' and 'classical', which leterally refer to these ancient states, have also come to mean 'the standard' or 'the best'. Classicism-the reverence for Greek and Roman culture, especially literature, art, and architecture-is marked by a dedication to reason, restraint, elegance, harmony, and clarity, and has been a defining characteristic of Western culture througout its history (Patricia S. Daniels, Patricia S \& Hyslop, Stephen G, 2003, p. 20).
}

Periode Klasik di dalam seni rupa memiliki pengertian yang berbeda dengan di bidang musik, bahkan di bidang filsafat dan sastra, bahkan memiliki pengertian yang berbeda di dalam sejarah musik sendiri, dengan munculnya periode Neo-Klasik, sebagai misal. Oleh karena itu pendefinisian serta pengkhususan istilah tersebut menjadi sangat penting supaya tidak menimbulkan kerancuan pemahaman. Istilah 'Klasik' ini awalnya digunakan berkaitan dengan keagungan kebudayaan Yunani dan Romawi kuno yang pernah mendominasi di Eropa. Istilah ini mulai ngetrend kembali di sekitar paruh kedua abad ke-18 bersamaan dengan munculnya nilai-nilai klasik dari Yunani Kuno, seperti keseimbangan, pengendalian, dan kejelasan. Awalnya istilah ini dipakai di bidang sastra dan arsitektur. Untuk urusan ini istilah yang digunakan adalah 'klasisisme'.

Hal yang sangat mencolok secara sosial di dalam periode ini adalah semakin kentaranya pemisahan antara kelas sosial bangsawan dengan gereja (hierarki gereja Katolik Roma). Pada saat dekade awal sering dihubung-hubungkan kembali dengan zaman pencerahan (age of enlightenment) yang mengagung-angungkan rasio lebih dari segalanya. Periode ini ditandai oleh ketertarikan baru pada perbaikan kondisi manusia melalui sains, teknologi, dan filsafat sosial. Salah satu tokohnya adalah Benjamin Franklin yang berdiri sebagai simbol dari suatu generasi yang memiliki perhatian pada pemenuhan praktis individu dan hubungan individu dengan negara. Dengan demikian hal ini menegaskan kemandirian untuk lepas dari pengaruh otoritas gereja Katolik yang terlalu dominan atau monarki absolut yang sebelumnya sangat kuat mempengaruhi jalannya sejarah (Crick, 1987, p. 24-46). Hal inilah yang menjadi salah satu pemicu terjadinya Revolusi Amerika dan Revolusi Perancis. 
Klasik adalah sebuah periode yang merupakan reaksi dari Barok. Secara sosial, masyarakat periode ini mulai bosan dan enggan berhubungan dengan hal-hal yang rumit (complicated). Hal itu mempengaruhi paradigma dalam menilai musik. Cara-cara kontrapungtis, canon, dan yang berbau karya toccata, tampaknya tidak lagi menarik bagi sebagain besar komponis di zaman itu. Kesederhanaan merupakan warna utama pada gaya klasik menunjukkan suatu penolakan atas kerumitan yang kerap mewarnai karya musik di masa Barok. Namun demikian, di balik kesederhanaan itu keteraturan yang tinggi, keseimbangan, serta kesimetrisan merupakan ciri khas zaman Klasik.

Berbeda dengan Barok yang menekankan pada alur bas yang kuat, musik Klasik lebih menekankan pada orisinalitas dan natur melodi yang ekspresif dan sering dipakai sebagai sarana menyampaikan mood. Potensi emosional dari melodi mengalami eksplorasi luas dan pengorganisasian materi melodi cenderung linier. Jika pada musik Barok penekanan pada aliran melodi yang mulus dan tidak terputus, maka pada masa Klasik lebih condong memberi kesan adanya proporsi, yakni dengan adanya frasa-frasa sebagai pembentuk melodi. Harmoni lebih berkembang dengan pemanfaatan modulasi untuk menghindari sifat monoton. Polifoni yang dominan pada masa Barok mulai tergusur oleh tekstur monofoni. Dengan demikian, bentuk-bentuk musik yang berkembang di masa Barok lebih tereksploitasi di masa Klasik.

Dari uraian singkat mengenai zaman Barok dan zaman Klasik, maka dapat dilihat bahwa peran teknologi sangat mempengaruhi perubahan-perubahan musik di masa itu. Aspek-aspek yang mempengaruhi adalah aspek-aspek eksternal. Hal-hal yang menjadi ikon di masa renaisans, seperti perkembangan sastra, ilmu pengetahuan, arsitektur, dan filsafat pada gilirannya mempengaruhi bidang musik di masa ini, berbarengan dengan mulai adanya pemisahan antara negara dan gereja (Block, 1964, p. 223). Kaum bangsawan menjadi kelompok baru yang sangat berpengaruh di berbagai bidang dan pada gilirannya menciptakan 'selera'nya sendiri di bidang musik. Jika pun terjadi perubahan internal, maka perubahan tersebut hanya berkisar pada pengembangan-pengembangan bentuk serta perubahan-perubahan nilai estetis, yang pada hakikatnya telah dikembangkan sedemikian rupa di era Barok, sehingga tampak sebagai nilai estetis tersendiri. Dengan kata lain, perubahan yang disebabkan faktor eksternal lebih mendominasi dibandingkan faktor internal yang berlangsung selama 70 tahun, yakni sampai tahun 1820 . 


\section{Periode Romantik}

Zaman Klasik ternyata berlangsung bukan tanpa kritik. Walaupun terdapat kelebihan-kelebihan, musik ini masih dianggap 'kaku'. Sebagai reaksinya, maka di awal abad ke-19 muncullah sebuah gerakan yang disebut 'Romantisisme'. Gerakan ini merupakan suatu gerakan kebudayaan yang memberikan penekanan pada emosi, imajinasi, dan individualisme. Secara umum, gerakan ini muncul sebagai reaksi atas atas Aufklarung yang didominasi pada pemikiran Rasionalisme-suatu gerakan yang menekankan pada keutamaan rasio manusia dan turut mempengaruhi kesenian. Dikarenakan sifatnya yang cenderung subjektif, maka gereka ini sulit didefinisikan secara pasti. Sebagian seniman memilih mengarahkan karya-karyanya di masa depan yang utopia, sementara sebagian lagi lebih menganggap masa lalu, terutama Abad Pertengahan sebagai periode ideal yang cocok dijadikan patokan. Tidak sedikit karya literatur Eropa di masa itu mengambil Abad Pertengahan sebagai settingnya. Di bidang arsitektur pun ada semacam kebangkitan gaya gothic dari Abad Pertengahan. Selain itu, eksplorasi alam fantasi, irasional, dunia dongeng, mimpi, serta dunia yang menakutkan, serta supranatural turut menjadi fokus dari karyakarya zaman Romantik (Burkholder, 2005, p. 602-603).

Paradigma umum tersebut mempengaruhi karya-karya musik Romantik, yang akhirnya berkembang menjadi ciri musik itu sendiri. Jika dibandingkan, ada beberapa hal yang menjadi ciri yang membedakan musik musik Romantik dengan musik-musik di zaman sebelumnya yakni pertama, tidak sedikit bentuk komposisi yang bersifat miniatur: singkat; pendek; dimainkan hanya di dalam ruang kecil, walau ada juga yang monumental: panjang; dimainkan di pentas oleh sejumlah besar pemain musik/ penyanyi. Kedua, harmoninya lebih variatif dan mulai meninggalkan ilmu harmoni klasik. Ketiga, melodi bersifat liris dan dominan di dalam konposisi. Keempat, ritme cenderung lebih bervariasi dan kompleks. Kelima, warna suara lebih kaya variasi dan lebih ekspresif. Keenam, jangkauan nada, dinamika, dan tempo semakin luas. Ciri-ciri di tas sebagian besar sebagian besar terdapat di dalam bentuk-bentuk musiknya, yakni di dalam opera romantik, oratorio romantik, musik gereja, nyanyian, musik piano, musik kamar, dan musik orkestra.

Perkembangan musik Romantik secara garis besar dibagi menjadi beberapa fase yakni, pertama, romantik Awal (1800-1830). Fase ini diawali dengan gerakan restorasi di Jerman. Cerita-cerita rakyat dan dunia dongeng menjadi sumber bagi penulisan karyakarya komposisi. Kedua, Romantik Tinggi (1830-1850). Dalam fase ini gaya romantik telah menjadi umum di Eropa. Paris, Perancis, menjadi pusat perkembangannya, walaupun 
musik Romantik di Italia dan Jerman juga mengalami perkembangan yang khas. Ketiga, Romantik Akhir (1850-1890). Dalam fase ini bentuk-bentuk musik baru bermunculan disertai tampilnya generasi komponis-komponis baru dengan estetika dan bentuk yang baru.

Keempat, Masa Pergantian Abad. Di dalam fase ini bentuk musik semakin ekstrim dan abstrak. Komponis-komponis di Zaman Romantik di antaranya Carl Maria von Weber, Gioacchino Antonio Rossini (1792-1868) dengan karyanya yang terkenal Il Barbiere di Siviglia (The Barber of Seville), Gaetano Donizetti (1797-1848), Vincenzo Ballini (18011835), Giuseppe Verdi(1813-1901) dengan karyanya yang terkenal Aida. Pietro Mascagni (1863-1945), Ruggiero Leoncavallo (1857-1919), Charles Gounod (1818-1893), J. Offenbach (1819-1880), Hector Berlioz (1803-1869), Camille Saint-Saen (1835-1921), George Bizet (1838-1875), dan Jules Massenet (1842-1912), F.F. Chopin (1810-1849), R. Schumann (1810-1856), F. Liszt (1811-1886), Richard Wagner (1813-1883), Anton Bruckner (1824-1896), J. Brahms (1833-1897), P. Ilych Tchaikovsky (1840-1893), dan Johann Strauss (1825-1899) yang banyak sekali menulis musik waltz (Kupferberg, 1985, p. 12-17).

Berdasarkan uraian tersebut, jika melihat perubahan-perubahan musik di masa Romantik lebih banyak dipengaruhi oleh fenomena sosial, terutama penekanan pada individu. Di masa ini musik mendapat perhatian yang cukup baik dari berbagai kalangan, termasuk para filsuf. Musik mulai dianggap sebagai bidang yang cukup penting, bahkan pada masa-masa berikutnya. Schopenhaouer pernah berujar, bahwa musik adalah satusatunya seni yang memiliki hakikat yang paling murni sebagai sarana komunikasi. Estetika musik pun berkembang. Berbagai kajian mulai dilakukan, dan pada gilirannya disepakati bahwa musik merupakan bahasa yang universal. Aspek-aspek tersebut bersifat eksternal dan internal. Artinya, perubahan-perubahan yang terjadi pada aspek eksternal mempengaruhi secara signifikan pada aspek internal.

\section{Periode Modern}

Istilah 'modern'5 memiliki makna yang begitu beragam. Oleh karena begitu banyaknya pengertian 'modern', sampai-sampai tidak jelas sejatinya definisi ini. Di setiap

5 Istilah ini memiliki makna yang sangat kompleks, bahkan turunannya seperti 'modernitas', 'modernisasi', atau postmodern, memiliki pengertian yang berbeda-beda tergantung perspektif dan konteksnya. Yang terakhir lebih kompleks lagi, bahkan diragukan keberadaannya. 
bidang, bahkan pun bidang-bidang eksakta, istilah ini memiliki pengertiannya sendiri. Socrates sering disebut 'Bapak Filsafat Modern Yunani'; Rene Descartes dijuluki 'Bapak Filsafat Modern', padahal Socrates dan Descartes hidup di masa dengan rentang waktu yang sangat jauh, bahkan Nietszche dianggap sebagai perintis gerakan post-modernisme lantaran dianggap kritis terhadap rasionalitas modern. Dalam bidang musik, Debussy sering dianggap sebagai komponis yang merintis gerakan 'musik modern' (Hardiman, 1993, p. 178). Sebagian sosiolog menganggap era modern dimulai sejak diciptakannya mesin uap. Ahli lain mengatakan zaman modern adalah ketika manusia mulai mengenal listrik, atau berkembangnya sistem ekonomi global, dan masih banyak lagi fenomena kesimpangsiuran terminologi ini. Yang jelas, istilah ini harus diartikan berdasarkan perspektif yang mengartikan. Perspektif tersebut tentu berdasarkan pada lingkungan, perkembangan teknologi, pengalaman, wawasan, way of life, serta perasaan orang yang mengartikannya. Dengan kata lain, masyarakat modern adalah suatu komunitas dunia yang disebabkan oleh gerakan renaisans yang buahnya oleh Horkheimer disebut 'rasio instrumen', oleh Adorno sebagai 'pemikiran identitas', dan oleh Herbert Marcuse disebut 'rasionalitas teknologis' (Hardiman, 1993, p. xvii).

Secara filosofis masyarakat modern memiliki ciri khasnya. Soekanto menunjukkan bahwa masyarakat modern adalah pertama, masyarakat yang bersifat terbuka terhadap penemuan-penemuan baru. Kedua, senantiasa menerima perubahan. Ketiga, memiliki kepekaan terhadap lingkungan. Keempat, memiliki informasi yang lengkap mengenai lingkungannya. Kelima, berorientasi pada masa kini dan mendatang dan keenam, memiliki kesadaran akan potensi-potensi yang dimilikinya. Akan tetapi Hauser (1964, p. 553), seorang sosiolog termasyur abad ini dengan sangat cerdas menyatakan bahwa sekurangkurangnya terdapat dua karakter masyarakat modern yaitu pertama, masyarakat yang anggota-anggotanya senantiasa disusupi rasa mudah bosan-boredom-, dan kedua, masyarakat yang selalu dirundung kegelisahanan_restlessness-(Hauser, 1982, p. 580).

Pernyataan Hauser sangat nyata jika dilihat dari sisi perkembangan masyarakat. Fenomena-fenomena sosial, politik, ideologi, dan seni secara faktual telah disusupi oleh kedua karakter tersebut. Kritik-kritik ideologi, sosial, dan seni menunjukkan secara jelas melalui fenomena-fenomenanya. Seni secara khusus, kebosanan dan kegelisahan itu tampak dari runtuhnya kesepakatan-kesepakatan di dalam simbol-simbol yang digunakan. Dalam konteks musik, penggunaan simbol musikologis mulai bercorak individual (Kaemer, 1993, p. 37). Beberapa karya komponis-komponis modern menunjukkan hal itu 
sehingga membutuhkan pemahaman terhadap 'kesepakatan baru' untuk bisa memainkannya. Maka, 'bahasa musik' yang universal itu mulai semakin kabur (Cooke, 1989, p. 45-46), atau yang menurut bahasa Nietzsche, "musik sebagai bahasa simbol dunia" (Hamilton, 2007, p. 79) mulai terkoyak.

Fenomena lain yang cukup menarik adalah digunakannnya istilah 'kontemporer'. Istilah ini sejatinya berarti 'sesaat' atau 'kekinian'. Akan tetapi istilah ini juga tidak mudah diterjemahkan karena memiliki makna yang beragam. Di bidang musik, istilah ini memiliki pengertian yang berbeda jika dibandingkan dengan bidang seni rupa. Khusus dalam bidang musik hampir tidak bisa dibedakan antara 'musik modern' dengan 'musik kontemporer' jika dipandang dari keberlanjutan sejarah musik Barat yang telah dirintis sejak Abad Pertengahan sampai Tchaikovski (Munro, 1969, p. 34-35). Di Indonesia, karya-karya musik seperti Slamet Abdul Sjukur, Otto Sidharta, Royke B. Koapaha, dan Tony Prabowo masuk dalam kategori ini. Hampir semua karya-karya mereka menggunakan 'kesepakatan musikologis' yang berbeda-beda. Mungkin tidak terlalu berlebihan jika dikatakan bahwa nilai estetis musik modern sangat tergantung pada cara penikmat musik ini menangkap sisi-sisi folosofis yang terkandung di dalam karya tersebut, yang notabene menyampaikan suatu pesan tertentu.

Fenomena lain berkaitan dengan istilah 'kontemporer' di dalam konteks musik adalah musik-musik yang menggunakan combo (William, 1982, p. 611). Di dalam gereja Kristen, terutama beraliran karismatik, istilah 'musik kontemporer' sering diartikan musik dengan menggunakan alat musik band, atau musik-musik yang bersifat 'non-klasik' atau musik-musik yang bercorak himne (hymn). Tampaknya hal ini untuk membedakan gambaran satu denominasi dengan denominasi yang lain. Di dalam gereja bercorak karismatik bahkan genre memegang peranan yang sangat penting. Diterimanya musik pop, rock, jazz, bahkan dangdut semakin menegaskan bahwa musik kontemporer adalah musikmusik yang banyak disukai oleh masyarakat banyak (well-known) (Mac Donald, 1964, p. 21-26). Oleh karena itu tampaknya agak sulit dibedakan spesifikasi dari musik-musik yang telah disebutkan tersebut. Yang jelas, jenis musik-musik itu hampir sama sekali tidak dibedakan dengan 'musik pop', bahkan jika ditinjau dari ciri-ciri musikologisnya. Penggunaan musik-musik seperti itu memang dapat dipahami sebab musik-musik seperti inilah yang secara faktual strategis di dalam upaya penginjilan. Hal ini juga jadi mudah dipahami karena seperti dikatakan Wolff (1993, p. 75) bahwa sebuah karya seni merupakan konstelasi ideologi si seniman yang mencipta. 


\section{Kesimpulan}

Dari berbagai paparan yang sudah dijelaskan maka secara ringkas dapat disimpulkan bahwa musik pada hakikatnya tidak berdiri sendiri, tetapi dipengaruhi oleh berbagai aspek, baik yang bersifat internal maupun eksternal. Dalam rentang sejarah musik Barat dapat dilihat bahwa pengaruh-pengaruh tersebut berbeda dari satu periode ke periode yang lain. Pengaruh eksternal dapat dijelaskan bahwa terjadi perubahan yang mempengaruhi dari satu periode ke periode yang lain yakni politik keagamaan, perubahan sosial, perkembangan teknologi, dan perkembangan filsafat. Hubungan antara aspek internal dan eksternal juga bersifat korelatif. Kedua aspek ini tidak berdiri sendiri melainkan saling mempengaruhi. Dengan kata lain, perubahan estetika yang dipengaruhi oleh aspek internal tidak berlangsung begitu saja-dari dan oleh dirinya sendirimelainkan dipengaruhi oleh faktor eksternal. Akan tetapi terdapat satu aspek yang paling nyata di dalam perkembangan estetika musik Barat yakni teknologi. Sosok baru ini telah mengubah dunia musik Barat berkembang sedemikian rupa, sehingga mempengaruhi perubahan estetika yang begitu cepat sejalan dengan perkembangan teknologi. Dengan kata lain, untuk saat ini dan mungkin seterusnya, estetika musik sangat tergantung dari perubahan teknologi, dan hal itu berlangsung secara linear.

\section{Kepustakaan}

Apel, Willi. (1972). Harvard Dictionary of Music. Cambridge, Massachussetts: The Belknap Press of Harvard University Press.

Boskoff, Alvin. (1964). "Recent Theories of Social Changes," dalam Werner J. Cahnman dan Alvin Boskoff, Sociology and History: Theory and Research. London: The Free Press of Glencoe.

Block, Jenneth E. (1964). "Theories of Progress and Evolution", dalam Werner J. Cahnman dan Alvin Boskoff, Sociology and History: Theory and Research. London: The Free Press of Glencoe.

Burkholder, J. Peter, et.al. (2005). A History of Western Music. New York: Library of Congress Cataloging-in-Publication Data, sevent edition.

Cooke, Deryck. (1989). The Language of Music. New York: Oxford University Press.

Crick, Bernard. (1987). Concepts of Social Thought. University of Minnesota Press.

Daniels, Patricia S \& Stephen G. Hyslop. (2003). Almanac of World History. Washington D. C: National Geagraphic.

Fernandez, Stephanus Ozias. (1990). Citra Manusia Budaya Timur dan Barat. Flores, NTT: Nusa Indah. 
Hamilton, Andy. (2007). Aesthetics and Music. New York: British Library Cataloguing-inPublication Data.

Hardiman, F. Budi. (1993). Menuju Masyarakat Komunikatif: Ilmu, Masyarakat, Politik dan Postmodernisme menurut Jurgen Habermas. Yogyakarta: Kanisius.

Hauser, Arnold. (1982). The Sociology of Art. USA: Bloomington-Indianapolis.

Kaemer, John Edmund. (1993). Music in Human Life: Anthropological Perspective on Music. USA: University of Texas Press.

Kamien, Roger. (1994). Music: An Appreciation, Second Brief Edition. USA: Library of Congress Cataloging-in-Publication Data.

Kupferberg, Herbert. (1985). The Book of Classical Music Lists. USA: Library of Congress Cataloging-in-Publication Data.

Martopo, Hari. (2015). Musik Barat: Selayang Pandang. Yogyakarta: Panta Rhei Books Offset.

Mac Donald, Dwight. (1964). "A Theory of Mass Culture,". Dalam Rosenberg, Bernard \& White, David Manning (Ed.). Mass Culture: The Popular Arts in America. London: Collier Macmillan Publisher.

Merriam, Alan P. et.al. (1995). Etnomusikologi. Dalam Supanggah, Rahayu (Ed.). Yogyakarta: Masyarakat Seni Pertunjukan Indonesia.

Munro, Thomas. (1969). The Arts and Their Interrelation. London: The Press of Case Western Reserve University.

Nakagawa, Shin. (2000). Musik dan Kosmos. Jakarta: Yayasan Obor Indonesia.

Noth, Winfried. (1990). Handbook of Semiotics. USA: Library of Congress Cataloging-inPublication Data.

William, Raymond. (1982). "The Technology and the Society". Dalam Caldwell, John Thornton (Ed.). Electronic Media Electronic Media and Technoculture. London: The University of Chicago Press.

Wolff, Janet. (1993). The Social Production of Art. New York: New York University Press. 